NUKHBATUL 'ULUM : Jurnal Bidang Kajian Islam

Vol. 5, No. 2 (2019) : Hal. 145-157

Website: https://journal.stiba.ac.id

ISSN : 2685-7537 (online); 2338-5251 (Printed)

\title{
PERNIKAHAN BARU TANPA AKTA CERAI
}

\section{The New Marriage Without the Proof of Divorce}

\author{
Rosdalina Bukido \\ Institut Agama Islam Negeri Manado, Sulawesi Utara, Indonesia, Jl. Dr. S.H. \\ Sarundajang Kawasan Ring Road I Kota Manado, 95128 \\ Email: rosdalina.bukido@iain-manado.ac.id
}

\section{Christofer Visal Solang}

Institut Agama Islam Negeri Manado, Sulawesi Utara, Indonesia, Jl. Dr. S.H.

Sarundajang Kawasan Ring Road I Kota Manado, 95128

Email: christofer.solang@iain-manado.ac.id

\section{Ridwan Jamal}

Institut Agama Islam Negeri Manado, Sulawesi Utara, Indonesia, Jl. Dr. S.H.

Sarundajang Kawasan Ring Road I Kota Manado, 95128

Email: ridwan.jamal@iain-manado.ac.id

\section{Misbahul Munir Makka}

Institut Agama Islam Negeri Manado, Sulawesi Utara, Indonesia, Jl. Dr. S.H.

Sarundajang Kawasan Ring Road I Kota Manado, 95128

Email: misbahulmakka66@gmail.com

\section{Faradila Hasan}

Institut Agama Islam Negeri Manado, Sulawesi Utara, Indonesia, Jl. Dr. S.H.

Sarundajang Kawasan Ring Road I Kota Manado, 95128

Email: faradila.hasan@iain-manado.ac.id

\begin{tabular}{ll} 
Keywords : & \multicolumn{1}{c}{ ABSTRACT } \\
\cline { 2 - 3 } sociology; psychology; law & This study explains that Paradigms are a concept of thought that is acquired in \\
certain problems or cases so that the delivery can be understood and understood, the \\
problem being examined is the main factor of divorce what happened to the \\
community, not through the judiciary and the role of Islamic religious instructors in \\
responding to the new marriage process in the community of the Buku Raya village \\
in the Belang Disterict that did not have proof of divorce. The researcher \\
approached qualitative research (case study) in order to obtain data in the field \\
validly and aimed to describe and analyze critically what happened in the field so \\
as to produce data that the role of Islamic religious instructors in providing \\
understanding to society must be truly understood by the community itself so that \\
they are not easy to make decisions, and religious educators are also present from \\
people who have good religious understanding. This research is expected to be able \\
to provide advice and thoughts to the Community and the Government specifically \\
the Ministry of Religion in selecting and sorting extension workers in the religious \\
affairs office. \\
\hline \\
Penelitian ini menerangkan bahwa Paradigma merupakan suatu konsep \\
pemikiran yang di peroleh dalam berbagai masalah ataupun kasus tertentu \\
sehingga dalam penyampaianya dapat di pahami dan di mengerti, masalah \\
yang di teliti adalah faktor utama perceraian yang terjadi pada masyarakat tidak \\
melalui lembaga peradilan dan peran penyuluh agama islam dalam menyikapi \\
proses pernikahan baru pada masyarakat desa buku raya kecamatan belang
\end{tabular}


NUKHBATUL 'ULUM : Jurnal Bidang Kajian Islam

Website: https://journal.stiba.ac.id

ISSN : 2685-7537 (online); 2338-5251 (Printed)

yang tidak memiliki bukti cerai. Peneliti melakukan pendekatan penelitian kualitatif (case study) guna mendapatkan data dilapangan secara valid dan bertujuan untuk mendiskripsikan dan menganalisis secara kritis yang terjadi di lapangan sehingga menghasilkan data bahwa peran penyuluh agama islam dalam memberikan pemaham terhadap masyarakat harus benar-benar di pahami oleh masyarakat itu sendiri sehingga mereka tidak mudah mengambil keputusan, dan penyuluh agama juga di hadirkan dari orang-orang yang mempunyai pemahaman agama yang bagus. Penelitian ini diharapkan dapat memberikan saran dan pemikiran kepada Masyarakat serta Pemerintah khususnnya Kementerian Agama dalam memilih dan memilah tenaga kerja penyuluh di lingkungan kantor urusan agama.

Riwayat artikel : Diterima : 18 Desember 2019; Direvisi : 21 Desember 2019; Disetujui : 23 Desember 2019;

Tersedia online : 27 Desember 2019

How to cite : Bukino, R., Solang, C.V., Jamal, R., Makka, M.M., dan Hasan, F. (2019). Pernikahan Baru Tanpa

Akad Cerai. NUKHBATUL 'ULUM : Jurnal Bidang Kajian Islam, 5(2), $145-157$.

https://doi.org/10.36701/nukhbah.v5i2.88 


\section{PENDAHULUAN}

Perubahan zaman merupakan faktor penyebab terjadinya perubahan pola pikir di masyarakat, berbanding jauh dengan pemikiran terdahulu yang selalu berpatokan pada aturan yang telah ada sehingga jarang terjadi pelanggaran atas aturan tesebut. Masyarakat merupakan salah satu unsur yang menjalakan dan melaksanakan aturan tersebut demi menciptakan tatanan masyarakat yang saling menguntungkan antara satu dengan lainnya. Upaya dalam membuat aturan tersebut bertujuan agar semua masayarakat dapat merasakan keadilan dan ketertiban, dan jika terdapat masalah maka bisa diselesaikan dengan cara win-win solution. Namun, aturan-aturan yang diciptakan oleh masyarakat itu sendiri dilanggar tanpa berpikir panjang dampaknya kedepan. Aturan-aturan yang diterapkan di dalam masyarakat juga bukan hanya dari aturan yang dibuat dan disepakati masyarakat itu sendiri melainkan juga merupakan aturan yang di dilam kitab suci.

Aturan-aturan yang dibuat salah satuanya yang berkaitan dengan perkawinan. Ikatan dan tatacara perkawinan bukan hanya diatur dalam dalam aturan, tataran norma masayarakat akan tetap juga diatur dalam kitab suci yaitu Al-Quraan dan kitab-kitab agama lainnya. Secara bahasa kata perkawinan berasal dari kata "kawin" yang merupakan terjemahan dari bahasa Arab "nikah". Kata "nikah" mengandung dua pengertian, yaitu dalam arti yang sebenarnya (haqikat) berarti berkumpul dan dalam arti kiasan berarti aqad atau mengadakan perjanjian perkawinan.
Dalam hukum Islam yang dimaksud dengan perkawinan ialah aqad yang bersifat luhur dan suci antara laki-laki dan perempuan yang menjadi sebab sahnya sebagai suami isteri dan dihalalkannya hubungan seksual dengan tujuan mencapai keluarga yang penuh kasih sayang, kebajikan dan saling menyantuni, keadaan yang lazim disebut sakinah. Menurut Undangundang Nomor 1 Tahun 1974 tentang perkawinan (UUP) yang menyebutkan bahwa perkawinan ialah ikatan lahir batin antara seorang pria dengan seorang wanita sebagai suami isteri dengan tujuan membentuk keluarga (rumah tangga) yang bahagia dan kekal berdasarkan Ketuhanan Yang Maha Esa (Subekti, 2010).

Dalam undang-undang Nomor 1 tahun 1974 tentang Perkawinan pada pasal 2 ayat 1 dan ayat 2 terdapat dua penegasan yaitu tentang pelaksanaan dan pencatatan perkawinan untuk itu kedua unsur ini tidak dapat dipisahkan satu sama lain tetapi hendaknya ditafsirkan saling mengisi dan saling melengkapi karena perkawinan adalah sah apabila dilakukan menurut hukum masing-masing agama dan kepercayaannya dan untuk membuktikanya bahwa peristiwa perkawinan itu benar-benar telah terjadi maka perlu diadakan pencatatan. (Sekretariat-Negara-RI, 1974)

Adapun tentang syarat-syarat sah pelaksanaan perkawinan juga di atur dalam Undang-Undang Perkawinan pasal 6 sampai 12 Ketentuan tersebut terbagi atas dua bagian yaitu: (1) Syarat Materil (Syarat Intern) diatur dalam Pasal 6 sampai 11 UU Nomor 1 Tahun 1974; (2) Syarat Formil (Syarat 
Ekstern) diatur dalam Pasal 12 UU Nomor 1 Tahun 1974 dan Pasal 3 sampai 11 PP Nomor 9 Tahun 1975 Tentang Tata Cara Pelaksanaan Perkawinan (Bukido, 2016).

Pada Pasal 9 menjelaskan tentang bahwa seseorang yang masih terikat dengan tali perkawinannya dengan orang lain tidak dapat kawin lagi, kecuali mendapat izin yang sah dari pengadilan untuk memilki isteri (Poligami) dan bagi suami yang mau beristeri lebih dari satu maka harus melaporkan diri ke Pengadilan di daerah tempatnya serta Pengadilan akan mengeluarkan izin apa bila isteri tidak dapat menjalankan kewajiban, terdapat cacat fisik, dan tidak bisa melahirkan keturunan. Ketentuan mengenai waktu tunggu bagi seorang janda diatur dalam Pada Pasal 11 UU Nomor 1 Tahun 1974 dan Pasal 39 PP Nomor 9 Tahun 1975. Menurut Pasal 39 PP Nomor 39 Tahun 1975 bahwa waktu tunggu bagi seorang janda sebagaimana yang dimaksud dalam Pasal 11 ayat (2) UU Nomor 1 Tahun 1974 ditentukan sebagai berikut: (1) Apabila perkawinan putus karena kematian, waktu tunggu ditetapkan 130 hari; (2) Apabila perkawinan putus karena perceraian, waktu tunggu yang masih berdatang bulan ditetapkan 3 kali suci dengan sekurang-kurangnya 90 hari dan bagi yang tidak berdatang bulan di tetapkan 90 hari; (3) Apabila perkawinan putus sedang janda tersebut dalam keadaan hamil, waktu tunggu ditetapkan sampai melahirkan. (Presiden Republik Indonesia, 1975).

UUP menganut azas monogami, yakni seorang laki-laki hanya boleh memiliki satu isteri. Akan tetapi, UndangUndang Perkawinan tidak menutup rapat-rapat poligami. Laki-laki tetap memiliki peluang untuk melakukan poligami (memiliki lebih dari satu isteri) apabila syarat-syarat yang ditentukan oleh UUP terpenuhi (Gunawan \& Hasan, 2017). Azaz monogami ini disebut penulis sebagai azaz monogmi terbuka. Azaz monogami terbuka inilah yang menjadi dasar bahwa suami boleh melakukan poligami dengan syarat-syarat tertentu yang harus terpenuhi, namun jika isteri tidak menghendakinya, maka isteri bisa megajukan pemutusan ikatan perkawinan atau perceraian.

Perceraian adalah putusnya perkawinan, dengan kata lain bahwa perceraian adalah putusnya ikatan lahir batin antara suami dan isteri yang mengakibatkan berakhirnya hubungan keluarga (rumah tangga) antara suami dan isteri tersebut (Syaifuddin, et. Al, 2013). Hukum Indonesia hanya mengakui terjadinya perceraian yaitu dengan dibuktikan adanya akta cerai yang dikeluarkan oleh Pengadilan Agama. Putusnya perkawinan selain cerai mati hanya dapat dibuktikan dengan surat cerai berupa putusan Pengadilan Agama baik yang berbentuk putusan perceraian, ikrar talak, khuluk atau putusan taklik talak sesuai dengan pasal 8 dalam Kompilasi Hukum Islam.

Sesuai dengan ketentuan dan hukumhukum yang berlaku bahwa pentingnya pemahaman agama serta penerapananya sehingga masyarakat tidak hilang kepercayaan diri dalam melaksanakan kehidupan berumah tangga. Karena saat ini, banyak masyarakat yang larut akan kebiasaannya untuk berpisah dengan pasangannya sangatlah tinggi, penyebab dari terjadinya karena pasangan tidak memiliki keturunan, 
pernikahan dilakukan secara jarak jauh (long distance), suami tidak menafkahi dan jarang pulang, kekerasan dalam rumah tangga (KDRT), perekonomian keluarga belum mantap, kesenjangan ekonomi antara suami dengan isteri, penghasilan isteri jauh lebih tinggi dibanding suami, dan pihak perempuan yang tidak bersedia dimadu atau dipoligami, isteri yang membangkang terhadap suami (nusyus). Masalah-masalah yang seperti ini yang terjadi sehingga tingginya tingkat perceraian dan mudahnya melaksanakan perkawinan baru. (Prianto, Wulandari and Rahmawati, 2013).

Namun, perceraian dan perkawinan baru tersebut sering kali tidak tercatat, seihngga pemerintah mengalami kesulitan dalam mendata masyarakat. Implikasinya adalah pada status isteri dan anak dari hasil perkawinan baru yang tidak memiliki akta cerai pada pasangan sebelumnya.

Akibat hukum dari perkawinan yang dilakukan tanpa akte cerai dapat berakibat pada pembatalan perkawinan karena tidak memenuhi syarat perkawinan sesuai dengan ketentuan hukum yang berlaku, terhadap anak-anak yang dilahirkan, dari perkawinan yang dapat dibatalkan memiliki akibat hukum tetap, mempunyai hak untuk dipelihara dan dibiayai seluruh hidupnya oleh kedua orang tuanya, demikian juga tetap memiliki hak waris dari kedua orang tunya, terhadap harta bersama, bahwa narta yang diperoleh selama perkawinan berlangsung merupakan harta bersama bagi suami isteri (Sobari, Bachtiar, \& Fitriani, 2016). Namun hal ini terjadi jika perkawinan baru tanpa akta cerai dilakukan secara sah. Lain halnya jika perkawinan baru tersebut tidak sah secara hukum, maka jatuhnya perkawinan baru tersbut adalah perkawinan sirih. Sehingga status hukumnya menjadi berbeda yaitu terhadap isteri: tidak diakui sebagai isteri karena perkawinannya dianggap tidak sah; terabaikannya hak dan kewajiban; tidak berhak atas nafkah, warisan dan pembagian harta bersama. Terhadap anak akibatnya: anak hanya memiliki hubungan keperdataan dengan ibu kandung; anak tidak berhak atas nafkah, warisan dan hak-hak lainnya (Adillah, 2016).

Status anak di atas telah berubah setalah adanya putusan Mahkamah Konstitusi Nomor 46/ PUU-VIII / 2010, anak yang lahir di luar pernikahanmungkin memiliki hubungan perdata dengan laki-laki yang terbukti menjadi ayah biologisnya. Berdasarkan hal ini, Pasal 43 ayat (1) berbunyi: "anak-anak yang lahir di luar nikah memiliki hubungan perdata dengan ibu dan keluarga ibunya serta dengan ayah mereka dan keluarga ayah mereka dalam kasus hubungan biologis ini dapat terbukti secara ilmiah atau teknologi, dan/atau ada bukti lain seperti hubungan darah, termasuk hubungan sipil dengan keluarga ayah mereka dapat dibuktikan.

Secara keperdataan dalam hukum nasional di Indonesia setelah diterimanya usulan judicial review atas pasal 43 ayat (1) Undang-Undang Nomor 1 Tahun 1974 tentang Perkawinan pada Mahkamah Konstitusi (MK), maka diputuskan bahwa anak dapat memiliki hubungan keperdataan dalam pengertian sebagai pengesahan bahwa bapak biologis bertanggungjawab terhadap anak 
biologisnya terkait nafkah, pendidikan, dan lain sebagainya (Edyar, 2016). Hal tersebut merupakan bentuk perlindungan hak keperdataan anak luar nikah oleh pemerintah untuk memperoleh pemeliharaan dari kedua orangtua biologisnya (Nurhayati, 2017).

Keputusan hakim MK yang menilai pasal 43 ayat (1) UU Perkawinan sebagai inkonstitusional dengan alasan bahwa, anak yang sejatinya tidak bersalah ikut mengalami kerugian disebabkan kesalahan kedua orang tuanya dengan diabaikannya oleh ayah biologisnya yang sepatutnya menafkahinya, sehingga apabila dapat dibuktikan bahwa anak tersebut memiliki hubungan nasab dengan bapak biologisnya, maka anak tersebut memperoleh hubungan keperdataan dengannya (Aziz, n.d., 2017). Demikian pula bapak biologis anak tersebut dapat mengakuinya sebagai anak dengan syarat disetujui atau diakui pula oleh ibu kandungnya (Wardana, 2016), dalam hukum Islam hal tersebut diperbolehkan melalui mekanisme istilhaq (Taufiki, 2012), putusan dengan istilhaq didasarkan pada analisis mashlahah (Wahyudi, 2017). Hal tesebut sesuai dengan tujuan penjagaan nasab (hif žh an-nash) dalam maqashid syariab (Zakyyah, 2016).

Secara keperdataan dalam hukum positif, sebelum diterimanya usulan judicial review atas pasal 43 ayat (1) Undang-Undang nomor 1 tahun 1974 tentang Perkawinan pada Mahkamah Konstitusi (MK), anak yang lahir dalam perkawinan yang tidak dicatatkan atau anak luar nikah yang dalam hal tidak memiliki hubungan keperdataan dengan bapak biologis, artinya anak dan bapak biologisnya dianggap tidak memiliki hubungan nasab. Hal ini menunjukkan bahwa madzhab Syafi'i sangat mewarnai corak hukum keluarga di Indonesia dalam hal hubungan anak dan orangtua biologis (Sandimula, 2019).

Perceraian atau putusnya perkawinan tanpa akta cerai marak terjadi di Kecamatan Belang, Kabupaten Minahasa Tenggara. Tanpa disadari perceraian yang dilakukan tidak melibatkan lembaga peradilan, namun hanya dengan hasrat ingin berpisah maka dua pasangan tersebut mengakhiri hubungan perkawinannya. Setelah mereka berpisah, keduanya tidak melewati jangka yang panjang kemudian salah satu dari pasangan yang berpisah kemudian menglangsungakn perkawinan baru. Pada observasi awal terdapat dua pasangan suami isteri yang sudah menikah tetapi keduanya berpisah, dalam hal ini bercerai dengan suami maupun isteri sebelumnya tanpa melalui lembaga peradilan dan melaksanakan pernikahan baru dengan suami atau isteri baru tanpa akte cerai.

Pelaksanaan kawin lagi atau nikah baru tanpa memiliki akta cerai pada perkawinan sebelumnya banyak terjadi dan pelaksanaannya sudah tidak lagi melalui Kantor Urusan Agama (KUA) dengan alasan mereka harus mempunyai bukti cerai dari pengadilan. Pasangan yang akan nikah baru demi menghindari fitnah dan kecurigaan di masyarakat maka mereka lebih memilih di nikahkan oleh imam ataupun keluarga dengan memenuhi rukun dan syarat nikah saja tanpa tercatat sehingga tidak memperoleh buku nikah dengan kata lain pasangan tersebut melakukan perkawinan sirih. 
Berdasarkan fenomena tersebut yaitu perkawinan baru tanpa memiliki akta cerai dari pengadilan maka penulis tertarik untuk mengetahui seperti apa pemikiran masyarakat di Kecamatan Belang, Kabupaten Minahas Tenggara yang melakukan perceraian tanpa akta cerai kemudian melakukan perkawinan yang baru.

Penelitian ini dilakukan di Desa Buku Raya Kecamatan Belang, Kabupaten Minahas Tenggara. Untuk mendapatakan informasi serta data yang valid maka peneliti menggunakan teknik penelitian lapangan (field research) (Narbuko, 2009), guna segala jenis data dapat di peroleh. Metode yang di pakai adalah penelitian kualitatif. Penelitian ini di pandang mudah apabila di hadapkan langsung dengan kenyataan, proses penyajian secara langsung hakekat hubungan antara peneliti dan respoden serta lebih dapat menyesuaikan diri dengan banyak pengaruh bersama terhadap pola-pola nilai yang dihadapi. Sehingga data dapat di olah secara mendalam dengan melihat dan menyaksikan langsung kondisi serta masalah dari objek yang menjadi pusat penelitian. Penulis juga melakukan observasi, wawancara dan studi dokumentasi lapangan guna mendapatkan data yang diinginkan, di samping itu juga dilandasi dengan penelitian kepustakaan dengan cara membaca buku-buku, jurnal serta artikel yang berkaitan dengan masalah yang dibahas (Moleong, 2010).

Pendekatan yang di lakukan oleh penulis dalam penyusunan artikel ini yaitu menggunakan pendekatan Studi Kasus (Case Study) yang merupakan jenis pendekatan yang digunakan untuk menyelidiki dan memahami sebuah kejadian atau masalah yang telah terjadi dengan mengumpulkan berbagai macam informasi yang kemudian diolah untuk mendapatkan sebuah solusi agar masalah yang diungkap dapat terselesaikan (Sarwono, 2006). Pelaksanan penelitian selama dua Bulan Di Daerah Pedesaan Tepatnya Di Desa Buku Raya Kecamatan Belang Kabupaten Minahasa Tenggara. Datadata yang sudah ada di analisis mulai dari pengumpulan data, pengelompokannya, memilih dan memilah data, serta menganalisa data. Setelah data terkumpul, kemudian dilakukan pengolahan data tersebut yang disesuaikan dengan kebutuhan analisis yang akan dkerjakan. Proses awal pengolahan data itu dimulai dengan melakukan editing setiap data yang masuk. Setelah editing selesai selanjutnya dilakukan analisis data. Dalam proses ini penulis menggunakan metode deksriptif. Teknik analisis data dekriptif yaitu penelitian yang bermaksud untuk membuat deskripsi mengenai situasisituasi atau kejadian-kejadian (Narbuko, 2009).

\section{PEMBAHASAN}

Lembaga peradilan agama merupakan lembaga yang mengurus perkaraperkara tentang agama islam yang di dalamnya seperti yang di atur dalam UU Peradlian Agama No. 50 tahun 2009 pasal 49.

Beberapa masyarakat yang kesulitan dalam pengurusan perkara perceraian di pengadilan karena kasus mereka di pandang berat terhadap pengadilan sehingga pengadilan meminta tarif yang tinggi dalam pengurusan perkara tersebut. Sehingga 
penulis memiliki ketertarikan untuk meneliti sebuah kasus yang merupakan kasus yang sudah menjadi kebiasaan masyarakat sejak dulu, yaitu melakukan perceraian tanpa melalui lembaga peradilan.

Pendekatan penyuluh agama terhadap keluarga yang mempunyai masalah sangatlah penting karena penyuluh agama di pandang mampu dan cakap terhadap masalah tersebut sehingga mampu memberikan solusi serta masukan dalam penyelesaian keluarga. Di Kecamatan Belang ini hanya memiliki satu Kantor Urusan Agama yang mengontrol dan mengawasi dua kecamatan yaitu Kecamatan Ratatotok dan Posumaen. Sehingga hanya terdapat delapan penyuluh agama yang terbagi di wilayah masing-masing dan hanya dua penyuluh agama mudah yang belatar belakang sarjana yang enam orang penyuluh agama lainya hanya dari lulusan yang berfariasi mulai dari SMP sampai SMA.

Dilihat dari latar belakang pendidikan, penyuluh yang ada di Kemenag yang mempunyai latar belakang pendidikan yang bervariasi. Beberapa penyuluh mempunyai latar belakang yang kompeten (sarjana), namun sebagian besar diantaranya tidak mempunyai latar belakang yang kompeten. Sebagaian penyuluh agama honorer pada awalnya merupakan guru pengajian di satu lokasi yang kemudian digaji dan diangkat oleh pemerintah sebagai bentuk penghargaan atas kinerja dan amal mereka yang selama ini ikhlas mengajar di masyarakat (Jaya, 2017).

Data yang peroleh penulis dari Kantor Urusan Agama Kecamatan Belang setelah melakukan penelitian, bahwa ternyata apa yang di harapakan mengenai peran dari penyuluh agama di daerah tersebut tidak maksimal karena tenaga peyuluh yang kurang serta tugas dari penyuluh tersebut sangatlah banyak mulai mengurus wakaf, hibah, serta hal-hal yang lain yang menjadi tanggungjawabnya. Bukan hanya fokus mengurus masalah munakahhat/perkawinan saja, seiring pula juga pemahaman munakahhat yang di miliki para penyuluh masih terbatas, ujar Kepala Kantor Urusan Agama setelah di wawancarai oleh Penulis.

Desa Buku Raya, merupakan desa yang terletak di Kecamatan Belang. Desa itu diapit oleh dua desa yakni Desa Belang dan Desa Ponosakan Indah. Proses jadinya penamaan Desa Buku Raya, ketika adanya pemekaran desa pada tahun 2004, awalnya desa ini memiliki daerah rawa-rawa yang besar kemudian setelah lama kelamaan rawarawa tersebut tiba-tiba kering maka berawal dari situlah desa ini terbangun kata Buku yang menjadi nama desa ini artiinya rawa dalam bahasa suku ponosakan. Desa ini terletak pada lintang utara $0^{\circ} .56^{\prime}$ 49.6", dan bujur timur $124^{\circ} 47^{\prime} 14.3^{\prime \prime}$ dengan ketinggian 20 meter di atas permukaan laut ini menandakan bahwa daerah tersebut berada di dataran rendah dan berdekatan dengan laut maluku. Adapun jumlah penduduk yang berada di desa ini adalah 1.161 jiwa dengan 145 Kepala Keluarga, dengan jumlah pekerjaan ada 50\% Petani, 20\% Nelayan, 20\% Buruh Tani dan PNS, $10 \%$ dan lainnya. Dari semua data tersebut terdapat tujuh kepala keluarga yang sudah berpisah tanpa ada kepastian hukum dari pengadilan. Penulis kemudian hanya mendapatkan satu kepala keluarga yang mau di 
Website: https://journal.stiba.ac.id

ISSN : 2685-7537 (online); 2338-5251 (Printed)

wawancarai tentang masalah keluargannya dari keenam lainnya.

\section{Penyebab Terjadinya Perceraian}

Perceraian merupakan sebuah keputusan akhir yang sangat baik ketika suatu keluarga tidak mampu meyelesaiakan konflik dalam keluarga secara terus menerus. Walaupun baik di mata manusia tapi buruk di mata Allah Swt. Penulis melihat beberapa kejadian seperti ini sering di lakukan oleh beberapa kalangan masyarakat yang tidak mampu menyelesaikan masalahnya, dengan berpatokan pada beberapa penyebab yang seharus dapat di selesaikan oleh pasangan suami isteri.

Konflik dalam keluarga pemicu segalanya salah-satunya perceraian yang dihasilkan dari konflik tersebut, untuk mengatasi konflik pernikaan bukanlah suatu masalah yang mudah, jika kedua pasangan masih di kendalikan oleh keegoisan dan tidak mau melangkah maju, serta berusaha untuk memperbaiki konflik tersebut. Tetapi konflik akan selesai, jika pasangan suami-isteri mau mengadopsi prinsip saling menerima dan saling memberi, dalam arti terbuka kepada pasangan, sehingga tindak lanjut untuk mengatasi konflik dapat dilakukan.

Setelah berlangsungnya peneitian selama dua bulan di daerah yang menjadi target penelitian. Penulis mendapatkan data-data tambahan dalam melengkapi tulisan ini yaitu sebab-sebab terjadinya perceraian dalam salah satu keluarga yang di teliti antara lain;

1. Isteri tidak lagi melaksanakan kewajiban sebagai isteri.
2. Isteri sering membangkang nasihat suami.

3. Isteri mencari alas an untuk kerja jauh.

4. Isteri meninggalkan suami tanpa se-izin suami selama 2 tahun sejak 2015 dan tidak pernah ada kabar.

5. Balik kekampung tanpa sepengetahuan suami.

6. Terbukti isteri sudah kawin tanpa bercerai.

Sebab-sebab terjadinya perceraian paling utama yaitu sikap isteri dalam hal ini membangkang perkataan suami dan tidak mau mencari jalan keluar bersama untuk menyelesaikan masalah. Terbukti bahwa isteri melakukan nusyuz, terhadap suaminya, dalam pemahaman penulis nusyur ini merupakan sebuah pembangkangan ataupun sikap durhaka kepada suaminya tanpa alasan yang dapat di terima oleh syara'. Adapun beberapa perbuatan yang di lakukan isteri, yang termasuk nusyuz, antara lain sebagai berikut :

1. Isteri tidak mau pindah mengikuti suami untuk menempati rumah yang telah disediakan sesuai dengan kemampuan suami, atau isteri meninggalkan rumah tanpa izin suami.

2. Apabila keduanya tinggal di rumah isteri atas se-izin isteri, kemudian pada suatu ketika isteri melarangnya untuk masuk ke rumah itu dan bukan karena hendak pindah rumah yang disediakan oleh suami,

3. Isteri menolak ajakan suaminya untuk menetap di rumah yang disediakannya tanpa alasan yang pantas.

4. Apabila isteri bepergian tanpa suami atau mahramnya walaupun perjalanan itu wajib, seperti haji, 
karena perjalan perempuan tidak dengan suami atau mahramnya termasuk maksiat (Tihami, 2014).

Allah berfirman dalam QS. An-Nisa : 34.

"wanita-wanita yang kamu kha

watirkan nusyuz-nya, Maka nasehatilah mereka dan pisahkanlah mereka di tempat tidur mereka, dan pukullah mereka, kemudian jika mereka mentaatimu, maka janganlah kamu mencari-cari jalan untuk menyusahkannya"

Ayat dia atas menjelaskan bahwa ketika isteri melakukan nusyur inilah tugas yang harus di lakukan oleh suami, dari hasil wawancara nasrumber yang bersangkutan tersebut bahwa suami tersebut sudah pernah melakukan langkah-langkah seperti yang ada pada ayat tersebut akan tetapi isteri tidak pernah mau merubah malahan isteri memandang suaminya melakukan kekerasan. Dari segi hak dan kewajiban suami isteri bahwa antara suami isteri mempunyai hak dan kewajibanya masing-masing yang dapat mengikat keduanya akan tetapi apabila melanggar atau tiidak melaksanakan beberapa ketentuan hak dan kewajiban tersebut maka akan terjadi perselisihan dan keduanya masing dapat melaporkan ke Pengadilan Agama.

\section{Penyuluh Agama dan Nikah Baru Tanpa Akte Cerai}

Sejak semula penyuluh agama berperan sebagai pembimbing umat. Dengan rasa tanggung jawab tinggi, mereka membawa masyarakat kepada kehidupan yang aman dan sejahtera. Penyuluh agama ditokohkan oleh masyarakat bukan karena penunjukan atau pemilihan, apalagi diangkat tangan suatu keputusan, akan tetapi dengan sendirinya menjadi pemimpin masyarakat karena kewibawaannya. Penyuluh agama sebagai pemuka agama selalu membimbing, mengayomi dan menggerakan masyarakat untuk berbuat baik dan menjauhi perbuatan yang terlarang, menngajak kepada sesuatu yang menjadi keperluan masyarakatnya dalam membina wilayahnya baik untuk keperluan sarana kemasyarakatan maupun peribadatan (Kurniawan, 2011).

Peran serta penyuluh agama dalam pengembangan hukum perkawinan sangat diharapkan.Tidak dapat dipungkiri efektivitas penerapan hukum Islam dalam hal perkawinan sangat diharapkan upaya-upaya dari penyuluh agama sebagai leader dalam mengembangkan agama di daerah terpencil khususnya. Sehingga sangat menarik tentunya untuk diteliti secara mendalam mengenai sistem kerja penyuluh agama dalam pengembangan hukum perkawinan pada masyarakat pedesaan (Syamsuddin, 2019).

Pemberian pemahaman kepada masyakat tentang apa arti sesungguhnya perkawinan merupakan salah satu tugas dari penyuluh agama islam dari sekian tugas yang di laksanakan di suatu daerah dengan cangkupan kantor urusan agama yang bersangkutan. Di lokasi penelitian penulis sesuai data yang di peroleh bahwa tingkat produktifitas dan sumber daya penyuluh agama di daerah tersebut ternyata masih belum memadai.

Dari hasil wawancara tersebut penulis kemudian berpendapat bahwa ternyata 
kenapa perkawinan yang terjadi pada masyarakat di daerah tersebut kurang dari pemahaman yang kuat di karenakan jumlah penyuluh agama yang kurang memadai dan tidak sesuai dengan jumlah wilayah kerja mereka sehingga tidak banyak yang dapat di sampaikan kepada masyarakat tentang perkawinan dan juga menjadi perhatian sekarang bahwa pemerintah khususnya di rana Kementerian Agama Republik Indonesia harus menambah jumlah penerimaan penyuluh agama yang di ambil hanya 34 orang dari 34 provinsi menjadi meningkat seperti Kepala Kantor Urusan Agama. Tidak hanya di pedesaan, nikah baru pasca perpisahan tanpa akta cerai juga sering terjadi di perkotaan. Maka perlu juga penelitian lanjutan mengenai masalah ini yang berlokasi khusus di daerah perkotaan.

Karena pengetahuan dan ilmu dari penyuluh agama dapat di sampaikan kepada masyarakat yang pengetahuannya terhadap perkawiann masih kurang sehingga peran dari penyuluh agama dapat terlihat dan dapat tersalur kepada masyarakat sehingga ini juga merupakan perhatian kita bersama bahwa penyampaian ilmu yang kita peroleh harus tepat sasaran agar masyarakat yang tidak tau bisa paham serta bisa mengurangi angka perceraian di suatu daerah.

Ketika telah terjadi perpisahan antara suami isteri melaui putusan pengadilan maupun tidak dengan jangka waktu yang sangat lama sudah pasti salah satunya akan berfikir untuk mencari pasangan hidup untuk menemani kesehariannya, akan tetapi perceraian yang di lakukan tanpa ada putusan pengadilan masih terikat suami isteri walaupun sudah berpisah sangat lama.
Maka inilah pernikahan baru dilakukan oleh suami maupun isteri yang sudah berpisah sebelumnya.

Diketahui bahwa pernikahan baru yang di laksanakan tanpa perpisaha atau tanpa akta cerai dari pengadilan merupakan pernikahan sirih. Pernikahan sirih merupakan pernikahan yang sah secara rukun dan syarat akan tetapi di dalam hukum nasional di pandang tidak sah di karenakan tidak tercatat oleh negara dan tidak di catatkan di Kantor Urusan Agama. Pernikahan sirih sendiri di pandang oleh segolongan masyarkat yang minim pengetahuannya bahwa pernikahan tersebut di pandang sah dalam agama, akan tetapi ada sebagian masyarkat juga memandang bahwa pernikahan sah dilaksanakan berdasarkan ketentuan agama dan Negara karena berada pada rana Negara hukum. Sesuai dengan apa yang tertuang di dalam UU No.1 Tahun 1974 tentang Perkawinan.

\section{KESIMPULAN}

Faktor yang terjadi sehingga perceraian tidak di lakukan di pengadilan yaitu proses pengurusan di pengadilan sagatlah banyak di sebabkan karena lokasi maupun jarak dari isteri yang pergi jauh sangat susah di jangkau sehingga pihak pengadilan perlu biaya lebih akan tetapi suami yang melakukan pengajuan tergolong masyarakat lemah walaupun sudah memakai surat keterangan kurang mampu dari desa. Dari hal tersebut kemudian faktor lain juga muncul yaitu dorongan keluarga untuk melaksanakan nikah baru demi mengurangi fitnah jikalau sudah punya pasangan. Maka dari itu peran dan 
upaya dari penyuluh agamalah yang di perlukan dalam situasi seperti ini sehingga masyarkat di beri pemahaman yang baik dan matang tentang hukum negara da agama serta mampu menyelesaiakan masalah tanpa harus berujung pada perceraian dan semoga artikel ini dapat di jadikan bahan rujukan dan bahan perbaikan terhadap pemerintahan khususnya kementerian agama dalam menetapkan penyuluh agama.

\section{DAFTAR PUSTAKA}

Bukido, R. (2016) Perkawinan Masyarakat Bugis: Implementasi Undang-undang Nomor 1 Tahun 1974 Terbadap Perkawinan. 1st edn. Edited by M. Yaqi. Yogyakarta: Istana Publishing.

Moleong, L. J. (2010) Metodologi Penelitian Kualitatif. XXVII. Bandung: Remaja Rosdakarya.

Narbuko, C. (2009) Metode Penelitian. Jakarta: Bumi Aksara.

Presiden Republik Indonesia (1975) 'PP No. 9 Tahun 1975 Tentang Pelaksanaan UU Perkawinan', p. h. 11.

Prianto, B., Wulandari, N. W. and Rahmawati, A. (2013) 'Rendahnya Komitmen Dalam Perkawinan Sebagai Sebab Perceraian', Jurnal Komunitas: Research and Learning in Sociology and Anthropology, 5(2), p. h. 209. doi:

10.15294/komunitas.v6i1.2938.

Sarwono, J. (2006) Metode Penelitian Kuantitatif \& Kualitatif. I, Graha Imu. I. Yogyakarta.

Sekretariat-Negara-RI (1974) Undangundang Republik. Indonesia Nomor 1 Tabun 1974 Tentang Perkawinan, UU Negara Republik Indonesia. Jakarta: Yayasan Peduli Anak
Negeri (YPAN).

Subekti, T. (2010) 'Sahnya Perkawinan Menurut Undang-Undang Nomor 1 Tahun 1974 Tentang Perkawinan Ditinjau Dari Hukum Perjanjian', Jurnal Dinamika Hukum, 10(3), pp. 329-338.

Tihami, T. (2014) Fikih Munakabhat: Kajian Fikib Nikah Lengkap. Jakarta: Grasindo.

Syaifuddin, Muhammad., et. al. (2013). Hukum Perceraian, Sinar Grafika, Jakarta

Kompilasi Hukum Islam

Sobari, A., Bachtiar, M., \& Fitriani, R. (2016). Perkawinan Janda tanpa Akta Cerai di Kepenghuluan Karya Mukti Kecamatan Rimba Melintang Kabupaten Rokan Hilir. Jurnal Online Mahasiswa Fakultas Hukum Universitas Riau, 3(2), 1-15.

Adillah, S. U. (2016). ImplIkasI Hukum DarI perkawInan sIrI TerHaDap perempuan Dan anak. PALASTREN Jurnal Studi Gender, 7(1), 193-222.

Putusan Mahkamah Konstitusi Nomor 46/ PUU-VIII / 2010

Gunawan, E., \& Hasan, F. (2017). Divorce Lawsuit Due to Polygamy in the Manado Religious Court. Al-Mizan, 13(2), 272-293.

Kurniawan, A. (2011). Uregnsi Penyluh Agama. Jurnal Ilmu Dakwah. 5(17).

Syamsuddin, S. (2019). Efektivitas Peran Penyuluh Agama Islam dalam Penerapan Hukum Perkawinan Islam di Masyarakat Pedesaan (Studi Kasus di Kecamatan Mare Kabupaten Bone). Al-Risalah: Jurnal Hukum Keluarga Islam (Ahwal AlSyakbsiyab), 3(1), 96-112. 
Jaya, P. H. I. (2017). Revitalisasi Peran Penyuluh Agama Dalam Fungsinya Sebagai Konselor Dan Pendamping Masyarakat. KONSELING RELIGI Jurnal Bimbingan Konseling Islam, 8(2), 335-356.

Sandimula, N. S. (2019). The Status And Rights Of An Illegitimate Child According To Mazhab Asy-Syafi'i Perspective On The Development Of Islamic Family Law In Indonesia. Jurnal Imiah Al-Syir'ah, 17(2), 121-130.

Edyar, B. (2016). Status Anak Luar Nikah Menurut Hukum Positif dan Hukum Islam Pasca Keluarnya Putusan MK Tentang Uji Materiil Undang Undang Perkawinan. Al Istinbath: Jurnal Hukum Islam, 1(2).

Nurhayati, B. R. (2017). Constitutional Basis for the Civil Rights of Illegitimate Children. Pattimura Law Journal, 1(2).

Aziz, n.d. (2017). Nasab Anak yang Lahir di luar Nikah: Analisis Fatwa MPU Aceh Nomor 18 Tahun 2015 dan Keputusan MK Nomor 46/PUU/-VIII/2010. Samarab: Jurnal Hukum Keluarga Dan Hukum Islam, 1(1).

Wardana, A. A. (2016). Pengakuan Anak Di Luar Nikah: Tinjauan Yuridis Tentang Status Anak Di Luar Nikah. Jurisprudence, 6(2).

Taufiki, M. (2012). Konsep Nasab, Istilhâq, Dan Hak Perdata Anak Luar Nikah. Abkam, 12(2).

Wahyudi, M. I. (2017). Judges' Legal Reasoning On Child Protection Analysis Of Religious Courts' Decisions On The Case Of Child Parentage. Al-Jämíab: Journal of Islamic Studies, 55(1).
Zakyyah, Z. (2016). Nasab Anak Luar Kawin Menurut "Hifzhu Nasl". Jurnal Yudisial, 9(2). 